\title{
ADJUVANT RADIOTHERAPY OF BREAST CANCER - IS PARTIAL BREAST IRRADIATION SUFFICIENT?
}

\author{
MARTINA MIKULANDRA ${ }^{1}$ and LIDIJA BEKETIĆ-OREŠKOVIĆ ${ }^{1,2}$ \\ ${ }^{1}$ Division of Radiotherapy and Medical Oncology, University Hospital for Tumors, \\ Sestre milosrdnice University Hospital Center, Zagreb, Croatia; \\ ${ }^{2}$ Department of Clinical Oncology, School of Medicine, University of Zagreb, Zagreb, Croatia
}

\begin{abstract}
Summary
Partial breast irradiation is a relatively novel approach in adjuvant breast cancer radiotherapy. It involves administration of irradiation to a part of the breast, as opposed to the standard practice of irradiation of the whole breast. This method allows delivery of higher radiation dose to smaller volumes, and in shorter period of time. It can be delivered via standard linear accelerators, brachytherapy, or via mobile accelerator units which allow the delivery of a single dose of radiation to the tumor bed intraoperatively. However, the use of partial breast irradiation in standard clinical practice is still controversial. The level of evidence that supports its equality to the whole breast irradiation remains limited. While the results of some prospective randomized trials indicate its applicability in certain, highly selected patients, longer follow-up of patients is necessary to draw definitive conclusions.
\end{abstract}

KEY WORDS: breast cancer, adjuvant radiotherapy, breast-sparing surgery, partial breast irradiation

\section{ADJUVANTNA RADIOTERAPIJA RAKA DOJKE - JE LI DOVOLJNO DJELOMIČNO ZRAČENJE DOJKE?}

\section{Sažetak}

Djelomično zračenje dojke (engl. partial breast irradiation) je relativno novi pristup u provođenju adjuvantne radioterapije raka dojke. Za razliku od standardnog zračenja čitave dojke, djelomično zračenje obuhvaća samo dio dojke. Ova metoda omogućuje isporuku veće doze zračenja na manji ciljni volumen, u kraćem ukupnom vremenu. Mogu se koristiti standardni linearni akceleratori, brahiterapija ili mobilni akceleratori kojima se intraoperacijski ozrači ležište tumora. Liječenje djelomičnim zračenjem dojke je još uvijek kontroverzno jer je nedostatna razina podupirućih dokaza u odnosu na zračenje čitave dojke. Rezultati randomiziranih studija ukazuju da se takvo zračenje može provesti u određene skupine bolesnica. Za konačne zaključke potrebno je dulje praćenje bolesnica.

KLJUČNE RIJEČI: rak dojke, adjuvantna radioterapija, poštedna operacija dojke, djelomično zračenje dojke

\section{INTRODUCTION}

Radiotherapy (RT) is a crucial modality in the adjuvant treatment of breast cancer. It enables the breast-sparing surgery, reduces the probability of local recurrence and increases the overall survival of patients $(1,2)$. Traditionally, the standard adjuvant radiation treatment of the breast has consisted of administration of total radiation dose of 50 Gy in 25 daily fractions to the wholebreast area. This basically means that overall treatment time ranges approximately between five to 
six weeks (in case a boost is included). Such long duration of radiation therapy may impede the successfulness of treatment, especially when it is accompanied by circumstances which make it difficult for the patient to frequently travel to the treatment facility (long travel distance between the place of residence and the facility, old age, health impairment, etc.). It has been shown that only $12-77 \%$ of all patients who had underwent breast-sparing surgery have indeed received the prescribed dose of adjuvant radiation (3).

This prompted the conduction of studies which investigated the feasibility and effectiveness of shorter, hypofractionated regimes. The growing evidence that pointed in favor of such shortened regimes has led to the new recommendations of American Society for Radiation Oncology (ASTRO). The 2018 ASTRO guidelines recommend the use of hypofractionated regimes (4042.5 Gy in 15-16 fractions) in all cases of WBI, when nodal irradiation is not performed (4).

However, even shorter radiotherapy regimes lead to the unwanted side effects, which mostly occur within the target field and may appear during and after the completion of the RT course. In the case of the whole breast irradiation (WBI) the side effects involve the entire breast, as opposed to the partial breast irradiation (PBI), in which the target volume is much smaller. Further rationale for PBI offers the data that as much as $68 \%$ of ipsilateral recurrences occur within $3 \mathrm{~cm}$ radius around the tumor bed (5). This, in addition to the fact that the smaller treatment volume allows for the application of higher total radiation dose, this enabling even further shortening of the RT course, has prompted the idea of PBI.

\section{METHODS OF PARTIAL BREAST IRRADIATION}

The goal of PBI is to apply higher RT dose to only a part of the breast (which includes tumor bed) and in even shorter period of time than typical hypofractionated regimens that are delivered to the whole breast.

PBI of the breast can be performed via several different techniques, including external beam radiation therapy (EBRT), brachytherapy (both interstitial and intracavitary) and intraoperative radiotherapy (IORT).

\section{External beam radiation therapy}

PBI via EBRT is delivered postoperatively, through the use of linear accelerators. Both 3Dconformal and intensity-modulated radiotherapy (IMRT) techniques may be used, although IMRT allows for a higher dose to the target volume, with greater sparing of surrounding tissues. Doses in conformal radiotherapy typically range from 3538.5 Gy in 10 fractions, administered twice a day.

\section{Brachytherapy}

Brachytherapy is a radiotherapy technique which uses radioactive sources to deliver the desired radiation dose to the target. Radioactive sources may be temporarily placed into the postoperative cavity by the insertion of a catheter with inflatable balloon into the tumor bed cavity (intracavitary brachytherapy), or inserted via cathethers in the surrounding breast tissue (interstitial brachytherapy). Brachytherapy may be administered with either low or high dose rates. When using low-dose rate (LDR) brachytherapy, the usual dose is about 45-50 Gy delivered at a rate of 0.3-0.7 Gy per hour. The high-dose rate (HDR) brachytherapy is administered twice a day, over the course of five days, to the total dose of $34 \mathrm{~Gy}$.

\section{IORT}

With IORT, the entire therapeutic dose of radiation is delivered in a single fraction, into the tumor bed cavity immediately after tumorectomy, while the patient is still on the operating table. It can be performed through the use of mobile accelerators that generate an electronic field, or lowenergy photons.

\section{EFFICACY AND SIDE EFFECTS OF PBI}

The available data from prospective, randomized studies regarding the efficacy of PBI are limited. However, current findings seem to indicate that the method may be applicable in certain, carefully selected patients with early breast cancer (6). However, the results also point that PBI is associated with greater toxicity in comparison to the WBI. The complications include breast pain, erythema, edema, hyperpigmentation, symptomatic seroma, infection, fatty necrosis, teleangiectasia and fibrosis (7-9). 
The first randomized study that compared PBI to the WBI via EBRT was conducted in 1980's at Christie's Hospital. It included 708 patients, and the median follow-up was 5.4 years. In terms of local disease control, the results indicated clear inferiority of PBI in comparison to the WBI. The rates of local recurrences ranged between 15 and $34 \%$ in the group treated by partial irradiation, while the rates of local recurrences in the group that received WBI were almost halved, and ranged between $8-14 \%$ (10).

Although the results of some small non-randomized trials pointed toward good local control with satisfying cosmetic after partial irradiation of the breast $(9,11)$, the results of a large multicenter study, known as Randomized Trial of Accelerated PBI (RAPID) trial, have proven otherwise. Over 2000 patients ( $>40$ years, with histology of invasive ductal carcinoma or ductal carcinoma in situ $\geq 3 \mathrm{~cm}$ in size, clear margin and negative lymph nodes) were randomized into two groups (PBI in which 38.5 Gy in 10 fractions was applied to tumor bed vs. standard irradiation of the whole breast, including both $50 \mathrm{~Gy}$ in 25 fractions and $42.5 \mathrm{~Gy}$ in 16 fractions regimens). The results pointed towards higher rates of late toxicities and poorer cosmetic outcomes after the 3-year followup in the group received PBI compared to the group that received the WBI (29\% versus $16.5 \%)$ (12). The results of RAPID trial confirmed the observations of several smaller studies which also pointed toward greater toxicities and poorer cosmetic outcomes of PBI compared to WBRT $(8,13)$.

The safety and efficacy of interstitial brachytherapy following breast-sparing surgery has been investigated by several studies. Patients included in these studies mostly had tumors staged T1-2 N0-1, and had clear postoperative margins. The results indicated good local control with low rate of complications and satisfying cosmetic (1416). This prompts the conclusion that this method may be used in treatment of certain patients with early breast cancer. However, due to the complexity of the procedure, the method is rarely used.

Intracavitary brachytherapy, which is conducted by insertion of a catheter with inflatable balloon into the tumor bed cavity, is much more common. In the period between 2002 and 2004, 97 institutions participated in the registration study known as American Society of Breast Surgeons (ASBS) Registry Trial. In this study, 1449 patients with early breast cancer have undergone the treatment using MammoSite ${ }^{\circledR}$ applicator. Total dose of 38 Gy was delivered to the tumor bed in 10 BID fractions. The median follow-up was 60 months. The study reported low rates of local recurrences with good cosmetic and low rates of complications, which mostly involved symptomatic seroma and fatty necrosis (11). This prompted the development of more advanced devices, such as multi-lumen and multi-catheter devices, which enable greater conformity to the cavity and better dose distribution.

A retrospective study found that patients treated with this method had higher rate of mastectomy, when compared to patients treated with the WBI (17). Other studies have noted the increased rates of complications, such as fatty necrosis and rib fractures (5).

In the multicentric randomized Targeted Intraoperative Radiotherapy Trial (TARGIT-A), over 3400 patients (over 45 years of age with invasive ductal carcinoma) were randomized to receive either IORT or EBRT. In IORT group, a single dose of 20 Gy was delivered to the surgical bed using a spherical applicator. After 5 years, higher rates of local recurrences were noted in the IORT group ( $3 \%$ vs. $1 \%$ in the group that received WBRT). Additionally, it was shown that the whole-breast radiotherapy was subsequently conducted in $15 \%$ of the patients treated with IORT, due to the final biopsy report (18).

A single-institutional Milan (ELIOT) trial also showed higher rates of local recurrences in patients treated with IORT in comparison to standard WBRT. In the trial, a single dose of $21 \mathrm{~Gy}$ was delivered to the surgical bed via electrons. At 5 years, the rates of local recurrences in the IORT group were $5 \%$. In comparison, the recurrence rates in WBRT group were only $1 \%$. The authors concluded that the method should be approached with caution with careful selection of patients and high quality-control (19).

The results of a meta-analysis of 3 randomized phase III trials, which included 1140 patients and various methods of PBI, after a follow-up period of 4-8 years, showed no difference in overall survival, risk of distant metastasis or supraclavicular recurrences. However, the results showed a significant risk of local and axillary recurrences (20). However, this meta-analysis suffers from several limitations, including the variety of crite- 
ria for patient selection, different methods of PBI, of which some are no longer in use, and various definitions of target volumes.

In 2015, the results of a meta-analysis of 5415 patients yet again confirmed the higher rates of local recurrences in the group of patients who have undergone IORT in comparison to patients treated with standard WBRT (21).

In 2017, first results from IMPORT LOW, a large multicenter study conducted in the UK, were reported. 2018 patients were involved in the trial, and were randomized to three arms; one arm receiving $40 \mathrm{~Gy}$ in 15 fractions to the whole breast, the second receiving $36 \mathrm{~Gy}$ in 15 fractions to the whole breast and 40 Gy in 15 fractions to the partial breast, while the third arm received $40 \mathrm{~Gy}$ in 15 fractions only on the partial breast. The technique used was EBRT via intensive modulated radiotherapy (IMRT). The patients included were $\geq$ 50 years of age, with unifocal invasive ductal carcinoma of grade I-III, staged T1-2 N0-1, with clear surgical margins.

After 5 year follow-up, the cumulative incidence of local recurrence was $1.1 \%, 0.2 \%$ and $0.5 \%$ in the control group, reduced-dose group and partial breast group, respectively. The rates of adverse effects were similar between groups (22).

National Surgical Adjuvant Breast and Bowel Project and the Radiation Therapy Oncology Group (NSABP B39 / RTOG 0413) Trial is a large, multicenter, randomized, ongoing phase III trial which involves 4300 patients and compares the partial breast radiotherapy using EBRT (total dose of $34 \mathrm{~Gy}$ in 10 fractions is delivered to the target volume), to standard WBRT which is administered in 25 daily fractions up to total dose of 50 Gy in patients with early breast cancer. Hopefully, the results of this trial will help answer some of the existing questions, such as whether the PBI truly is as safe and as efficient as WBI for patients with early breast cancer, and whether the promising results observed in some other trials truly verify the efficacy of PBI, and are not merely reflection of some other, yet undetermined factors (23).

\section{DISCUSSION}

PBI has several advantages over WBI. The overall treatment time is shorter, which in turn may increase patient compliance, and increase number of patients that actually receive prescribed treatment dose. By reducing target volumes, it is possible to apply larger individual dose to the tumor bed, while enabling greater sparing of normal tissues. The results of several smaller non-randomized studies showed that PBI was as efficient and safe as the WBI were only recently supported by the first published results from the large IMPORT LOW phase III trial, that confirm PBI as a non-inferior adjuvant treatment in selected patients with early breast cancer. However, due to several important things, the use of PBI still remains controversial.

First, the evidence which support its non-inferiority to the WBI is limited. Patients that were included in trials that spoke in favor of PBI were carefully selected (aged 45-70 years, unifocal hormone positive low-grade T1-2 tumors resected with clear margins, without any of the adverse histologic features, such as the presence of at extensive intraductal component, ductal carcinoma in situ, or lobular carcinoma).

Second, all of the mentioned trials have limited follow-up period, which ranges between five to ten years. Therefore, there are still no data on the long-term efficacy and toxicity. Also, very few trials have compared different techniques of PBI. This is particularly intriguing in the case of IORT, one of the more popular methods of adjuvant radiotherapy, but also one with a particular disadvantage - the absence of final biopsy report in the time of treatment delivery.

Bearing this in mind, the current guidelines mostly agree that the current evidence is insufficient to recommend regular use of PBI in everyday clinical setting. National Cancer Comprehensive Network (NCCN) guidelines recommend the use of PBI in clinical trials, and accept the 2016 version of ASTRO guidelines of PBI. According to ASTRO guidelines patients suitable to PBI should be aged $\geq 50$ years, with T1-staged invasive ductal carcinoma, hormone receptor positive and BRCA negative, without the presence of lymphovascular invasion; or low to intermediate nuclear grade, clinically-detected ductal carcinoma in situ $\leq 25$ $\mathrm{mm}$ with clear margins at least $3 \mathrm{~mm}$ wide $(6,24)$.

In conclusion, while currently available data indicate that PBI certainly may be a safe and efficient alternative to WBI in certain number of care- 
fully selected patients, its application in regular clinical practice should wait for the results after a longer follow-up period and the more precise definition of the exact target patient population. Some of the controversies will hopefully be resolved by the results from the prospective NSABP B-39/ RTOG 0413 trial, which is currently ongoing.

\section{REFERENCES}

1. Fisher B, Anderson S, Bryant J, Margolese RG, Deutsch M, Fisher ER, et al. Twenty-year follow-up of a randomized trial comparing total mastectomy, lumpectomy, and lumpectomy plus irradiation for the treatment of invasive breast cancer. N Engl J Med. 2002; 347(16):1233-41.

2. Owen JR, Ashton A, Bliss JM, Homewood J, Harper C, Hanson J, et al. Effect of radiotherapy fraction size on tumor control in patients with early-stage breast cancer after local tumour excision: long-term results of a randomised trial. Lancet Oncol. 2006;7(6):467-71.

3. Ballard-Barbash R, Potosky AL, Harlan LC, Nayfield SG, Kessler LG. Factors associated with surgical and radiation therapy for early stage breast cancer in older women. J Natl Cancer Inst. 1996;88(11):716-26.

4. Smith BD, Bellon JR, Blitzblau R, Freedman G, Haffty B, Hahn C, et al. Radiation therapy for the whole wreast: An American Society for Radiation Oncology (ASTRO) Evidence-Based Guideline Conflict of Interest Disclosure Statement. Pract Radiat Oncol [Internet]. 2018; http://www.practicalradonc.org/cms/attachment/2119105247/2089218135/mmc1.pdf

5. Akhtari M, Teh BS. Accelerated partial breast irradiation: advances and controversies. Chin J Cancer. 2016; 35:31. Doi: 10.1186/s40880-016-0095-1

6. Correa C, Harris EE, Leonardi MC, Smith BD, Taghian AG, Thompson AM, et al. Accelerated PBI: Executive summary for the update of an ASTRO Evidence-Based Consensus Statement. Pract Radiat Oncol. 2017;7(2): 73-9.

7. Chao KK, Vicini FA, Wallace M, Mitchell C, Chen P, Ghilezan M, et al. Analysis of treatment efficacy, cosmetic, and toxicity using the MammoSite breast brachytherapy catheter to deliver accelerated partialbreast irradiation: The William Beaumont Hospital experience. Int J Radiat Oncol Biol Phys. 2007;69(1): 32-40.

8. Hepel JT, Tokita M, MacAusland SG, Evans SB, Hiatt JR, Price LL, et al. Toxicity of three-dimensional conformal radiotherapy for accelerated PBI. Int J Radiat Oncol Biol Phys. 2009;75(5):1290-6.

9. Chen PY, Wallace M, Mitchell C, Grills I, Kestin L, Fowler A, et al. Four-year efficacy, cosmetic, and toxicity using three-dimensional conformal external beam radiation therapy to deliver accelerated PBI. Int J Radiat Oncol Biol Phys. 2010;76(4):991-7.

10. Ribeiro GG, Magee B, Swindell R, Harris M, Banerjee SS. The Christie Hospital breast conservation trial: An update at 8 years from inception. Clin Oncol. 1993;5 (5):278-83.

11. Vicini F, Beitsch P, Quiet C, Gittleman M, Zannis V, Fine R, et al. Five-year analysis of treatment efficacy and cosmetic by the American Society of Breast Surgeons MammoSite breast brachytherapy registry trial in patients treated with accelerated PBI. Int J Radiat Oncol Biol Phys. 2011;79(3) 808-17.

12. Olivotto IA, Whelan TJ, Parpia S, Kim D, Berrang T, Truong PT, et al. Interim cosmetic and toxicity results from RAPID: a randomized trial of accelerated PBI using three-dimensional conformal external beam radiation therapy. J Clin Oncol. 2013;31(32):4038-45.

13. Jagsi R, Ben-David MA, Moran JM, Marsh RB, Griffith KA, Hayman JA, et al. Unacceptable cosmetic in a protocol investigating intensity-modulated radiotherapy with active breathing control for accelerated partialbreast irradiation. Int J Radiat Oncol Biol Phys. 2010; 76(1):71-8.

14. Arthur DW, Koo D, Zwicker RD, Tong S, Bear HD, Kaplan BJ, et al. Partial breast brachytherapy after lumpectomy: Low-dose-rate and high-dose-rate experience. Int J Radiat Oncol Biol Phys. 2003;56(3):681-9.

15. Benitez P, Chen P, Vicini F, Wallace M, Kestin L, Edmundson $\mathrm{G}$, et al. Surgical considerations in the treatment of early stage breast cancer with accelerated PBI (APBI) in breast conserving therapy via interstitial brachytherapy. Am J Surg. 2004;188(4 SPEC. ISS.): 355-64.

16. Strnad V, Ott O, Potter R, Hildebrandt G, Hammer J, Resch A, et al. Interstitial brachytherapy alone after breast conserving surgery: interim results of a German-Austrian multicenter phase II trial. Brachytherapy. 2004;3(3):115-19.

17. Smith GL, Jiang J, Buchholz TA, Xu Y, Hoffman KE, Giordano SH, et al. Benefit of adjuvant brachytherapy versus external beam radiation for early breast cancer: impact of patient stratification on breast preservation. Int J Radiat Oncol Biol Phys. 2014;88(2):274-84.

18. Vaidya JS, Wenz F, Bulsara M, Tobias JS, Joseph DJ, Keshtgar M, et al. Risk-adapted targeted intraoperative radiotherapy versus whole-breast radiotherapy for breast cancer:5-year results for local control and overall survival from the TARGIT-a randomised trial. Lancet. 2014;383(9917):603-13.

19. Veronesi U, Orecchia R, Maisonneuve P, Viale G, Rotmensz N, Sangalli C, et al. Intraoperative radiotherapy versus external radiotherapy for early breast cancer (ELIOT): a randomised controlled equivalence trial. Lancet Oncol. 2013;14(13):1269-77.

20. Valachis A, Mauri D, Polyzos NP, Mavroudis D, Georgoulias V, Casazza G. PBI or whole breast radiothera- 
py for early breast cancer: a meta-analysis of randomized controlled trials. Breast J. 2010;16(3):245-51.

21. Zhang L, Zhou Z, Mei X, Yang Z, Ma J, Chen X, et al. Intraoperative radiotherapy versus whole-breaste external beam radiotherapy in early-stage breast cancer: a systematic review and meta-analysis. Medicine (Baltimore). 2015;94(27):e1143.

22. Coles CE, Griffin CL, Kirby AM, Titley J, Agrawal RK, Alhasso A, et al. Partial-breast radiotherapy after breast conservation surgery for patients with early breast cancer (UK IMPORT LOW trial): 5-year results from a multicentre, randomised, controlled, phase 3, non-inferiority trial. Lancet. 2017;390:1048-60.
23. Norris D, Julian TB. Update on the NSABP B-39/RTOG 0413 Clinical Trial. 2008;(February):4-5.

24. https://www.nccn.org/professionals/physician_gls/ pdf/breast.pdf Accessed on 8 Oct 2018.

Corresponding author: Lidija Beketić-Orešković, Department of Clinical Oncology, School of Medicine, University of Zagreb, and Division of Radiotherapy and Medical Oncology, University Hospital for Tumors, Sestre milosrdnice University Hospital Center, Ilica 197, 10000 Zagreb, Croatia.e-mail: lidijabeketicoreskovic@gmail.com 